\title{
TERMINOLOGICZNE OSOBLIWOŚCI WŚRÓD METANAZW ONOMASTYCZNYCH W OBSZARZE FRANCUSKIM, ANGIELSKIM I WŁOSKIM
}

Słow a tematyczne: terminologia onomastyczna, osobliwości, nazwy własne, metanazwy, terminy analityczne, terminy syntetyczne

\section{WSTĘP}

Podczas XXI Międzynarodowej i Ogólnopolskiej Konferencji Onomastycznej poświęconej zagadnieniom terminologii onomastycznej i nazwotwórstwu profesor Barbara Czopek-Kopciuch zwracała uwagę na onomazjologiczne ujęcie, które leży u podstawy budowy wielu terminów używanych w onomastyce (Czopek-Kopciuch, 2020, s. 47). Trudno przyjąć inne podejście do „metanazewnictwa”, które choćby w zakresie specjalistycznego nazywania form onimicznych w sposób nader uzasadniony wychodzi od określonego leksykalnie konceptu obiektu lub zbioru obiektów wskazywanego przez dany termin (np. gr. ő $v \theta \rho \omega \pi$ o ${ }^{~}{ }^{\circledR}$ złowiek' > antroponim). Jak konstatowała polska Onomastka, ta i podobne metody onomastycznego „terminotwórstwa” są siłą rzeczy uzasadnione potrzebą indeksowania elementu rzeczywistości pozajęzykowej, nie zapewniają jednak ostrości i jednoznaczności, o których decydują nie same terminy, ale definicje ich pojęć (Czopek-Kopciuch, 2020, s. 48).

Podzielając ten pogląd, chciałbym w niniejszym artykule odpowiedzieć na pytanie, w jakim stopniu tworzone ad hoc terminy onomastyczne (TO) są gwarantami ich jednoznaczności semantyczno-funkcjonalnej. Ponadto interesuje mnie

${ }^{1}$ Jak dalece jest to naukowa praktyka dyskursywna, widać np. w konstatacji sformułowanej przez Walerego Pisarka (2021, s. 21): „W praktyce nazwą własną jest nazwa [podkreślenie A.G.], pod którą oznaczany przez nią przedmiot (tzn. instytucja, osoba, produkt, utwór, usługa itp.) występuje (lub występowałaby) [...]”. Metanazewnictwo można uznać za jeden z głównych obszarów zainteresowań metaonomastyki (por. Rutkowski, 2012). 
założenie rozszerzające podłoże onomazjologiczne TO o motywację semazjologiczną, szczególnie wówczas, gdy termin ma stanowić „nazwę nazwy” i tworzony jest z udziałem elementów pochodzących z języków klasycznych, greki i łaciny, ale także właściwych dla języka rodzimego. Przeglądowi poddaję zbiór francuskich, angielskich i włoskich TO, którym można nadać statut osobliwości, tak postrzeganych głównie przez onomastów, ale także przez ekspertów innych gałęzi językoznawstwa i dyscyplin, jak literaturoznawstwo, filozofia, geografia itd.

\section{KORPUS BADAWCZY}

Korpus zgromadzonych jednostek terminologicznych, w wielu przypadkach uznawanych za „nieprzyjęte”, w naukach onomastycznych pochodzi z różnych źródeł językowych, w tym francuskojęzycznego „Słownika terminów przydatnych do badania nazw miejscowych” („Lexique des termes utiles à l'étude des noms de lieux") Henriego Doriona i Jeana Poiriera, wydanego w 1975 roku w Kanadzie ${ }^{2}$; angielskiego „Alfabetycznego przewodnika po języku nazewnictwa” („An Alphabetical Guide to the Language of Name Studies”) Adriana Rooma (1996), jak również szeregu publikacji włoskich w formie zazwyczaj krótkich przyczynków wydawanych w „Rivista Italiana di Onomastica” w ostatnich dziesięcioleciach oraz glosariusza terminologii onomastycznej („Terminologia onomastica"), opublikowanego przez Enza Caffarellego i Caterinę Gagliardi w 2018 roku na łamach „Archivio per il Vocabolario Storico Italiano”.

Wychodząc jednak od obszaru słowiańskiego ${ }^{3}$, który, począwszy od wczesnych lat 60. XX wieku, mógł też dostarczać inspiracji twórcom terminologii onomastycznej w krajach Europy Zachodniej oraz za oceanem, a następnie oddziaływać na przeformułowania na pierwotnym gruncie słowiańskim, chciałbym się odnieść do jednego z pierwszych glosariuszy TO, mianowicie opracowania Jana Svobody z 1960 roku „K slovanské onomastické terminologii”, stanowiącego podstawę do sporządzenia przez przedstawicieli Komisji Onomastyki Słowiańskiej przy Międzynarodowym Komitecie Slawistów wielojęzycznego słownika TO w językach słowiańskich i niemieckim „Osnoven sistem i terminologija na slovenskata onomastika" (Vidoeski et al., 1983).

${ }^{2}$ Wiele terminów stanowiących ,nazwy nazw” w tym słowniku powstało na bazie propozycji proponowanych przez N. Podolską (1970).

${ }^{3}$ Ostatnio osiągnięcia obszaru słowiańskiego zostały podsumowane w pracy P. Odaloša i E. Vallovej (2020). 


\section{MODEL ANALITYCZNY}

Pionierskie ujęcie systemowe terminologii onomastycznej Jana Svobody wprowadzało model tworzenia „metanazw” głównie w formie analitycznej (deskryptywnej), co dość wiernie odtworzył Mieczysław Karaś na łamach „Onomastików” (1968) (np.: „2175 nazwa klasztorów i kościołów”, „2176 nazwa ulic”, „2233 nazwa leśna" itd.) ${ }^{4}$. Niektóre z tak konstruowanych wyrażeń stanowią jednocześnie najprostszą definicję uniwerbizowanego terminu, podanego jako uzupełnienie w formie syntetycznej, np.: „2201 nazwa powszechna (makrotoponim)”, ,2202 nazwa lokalna (mikrotoponim)”, „2221 nazwa górska (oronim)”, „23 nazwa terytorialna (choronim)". W znakomitej większości przypadków były to jednak propozycje wyłącznie analityczne, przejrzyste semantycznie i łatwo przekładalne między językami, dla pełniejszego zrozumienia opatrzone przykładami („30 nazwa rzeczowa”, „30021 nazwa dzwonów”, „3003 nazwa firmowa” itd.). Niemniej może tu zastanawiać kilka sformułowań, których wyjaśnienie staje się realne w konfrontacji czeskiego zestawienia Svobody i polskiego Karasia, np. „2236 nazwa komunikacyjna” to w oryginalnej wersji czeskiej „názvy cest, komunikací, průplavů, průhonů, železnic, mostu, les noms de routes protohistoriques et historiques” lub „3002 nazwa transportowa, np. express Ślask” odpowiadająca cz. ,jména dopravních prostředkư”.

Niektóre z ekwiwalentów polskich skłaniają do refleksji nad założeniem zgoła semazjologicznym, które stało u podstawy tworzonej „nazwy nazwy”, uznawanej za osobliwą, por.: „3005 nazwa zdarzeniowa, np. Rewolucja Październikowa, Odrodzenie”, „3006 nazwa konkursowa, np. Warszawska Jesień”, „3007 nazwa uroczysta, np. Dzień Dziecka”, „3010 nazwa artystyczna, np. Pan Tadeusz”. Chodzi zresztą o koncepty, które od momentu publikacji „Osnoven sistem... (Vidoeski et al., 1983) i takich prac jak ,Slovar' ruskoj onomastičeskoj terminologii” (Podolskaâ, wyd. 1 1978, wyd. 2 1988) zazwyczaj wyrażane są za pomocą syntetyzowanych form pochodzenia klasycznego, złożonych z wywodzonego

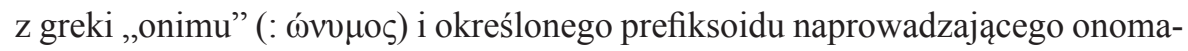
zjologicznie na przedmiot nominacji, typu ,ide/onim”, ,,heort/onim”, ,chremat/ onim" itd.

Dodać należy, że model terminotwórczy dominujący w wersji polskiej pionierskiego systemu Svobody polega na zestawieniu syntagmatycznym rzeczownika

\footnotetext{
${ }^{4}$ Ujęcie adaptacyjne M. Karasia było pierwszym krokiem w kierunku leksykograficznego opracowania polskiej terminologii onomastycznej. O stanie badań w tym zakresie w onomastyce polskiej i poszczególnych jej działach zob. np.: Bijak (2019), Czopek-Kopciuch (2020), Górny (2020).

${ }_{5}$ Szersza bibliografia prac leksykograficznych i innych studiów terminologiczno-onomastycznych w obszarze słowiańskim zob. Gałkowski (2020b, s. 25-29) oraz Odaloš i Vallová (2020).
} 
„nazwa” z dopełnieniem adiektywnym, którego interpretacja nie jest zazwyczaj jednoznaczna. Jest to podejście, które pozwala na objęcie zasięgiem terminologicznym zaskakująco szerokiego zbioru denominowanych obiektów lub uszczegółowień formalnojęzykowych i motywacyjnych w onimii (np. „2238 nazwa portowa” = cz. „názvy loděnic, př́stavních mol”; „4515 nazwa humanistyczna” =cz. ,jména humanistická a pod.”; „452 nazwa kalendarzowa” = cz. ,jména podle patronů, kalendářních světců").

Obecnie model analityczny metanazw stanowi alternatywny sposób ujęcia TO, w niektórych obszarach językowych jest on dominujący; zob. np. pojęcia omawiane w „The Oxford Handbook of Names and Naming” (Hough, 2016) typu ang. island names, rural names, commercial names, animal names, astronomical names ${ }^{6}$ itp.

\section{MODEL SYNTETYCZNY}

Jednocześnie od lat 70. XX wieku rozwija się i utwierdza tendencja w tworzeniu syntetyzowanych TO, teoretycznie ułatwiających przekaz naukowy na poziomie międzynarodowym, spotykających się jednak z różnymi opiniami i nie zawsze z zastosowaniem w uzusie terminologicznym na poziomie kraju, obszaru językowego lub międzynarodowego, stąd uznawanych w większości przypadków za osobliwe.

Dla bardziej przejrzystego zobrazowania zamieszczam wybór tego rodzaju TO w dwóch tabelach ${ }^{7}$. Pierwsza zawiera terminy francuskie (pochodzące z: Dorion \& Poirier, 1975) i angielskie (pochodzące z: Room, 1996), druga terminy włoskie (występujące w publikacjach ujętych w bibliografii). Kolumna pierwsza tabel 1 i 2 wskazuje w porządku alfabetycznym dany termin ${ }^{8}$; kolumna druga — pochodzenie elementu prefiksoidalnego ${ }^{9}$; kolumna trzecia — znaczenie nadane terminowi w źródle i ewentualną adaptację lub odpowiednik w obszarze polskim.

${ }^{6} \mathrm{~W}$ każdej z tego rodzaju syntagm element w prepozycji względem rzecz. names spełnia funkcję przymiotnika.

${ }^{7}$ Zestawienia nie obejmują większości dobrze przyswojonych TO typu: antroponim, toponim, hydronim, hagionim, teonim, fitonim, zoonim itp.

${ }^{8}$ Termin oznaczony gwiazdką należy uznać za nieprzyjęty lub wycofany z terminologii onomastycznej bądź podlegający dyskusji naukowej w zakresie jego potencjalnego statusu TO.

${ }^{9}$ Podane objaśnienia zazwyczaj nie występują w źródłach rozpatrywanego korpusu, co można uznać za ich niedopracowanie jako materiałów terminologicznych. Wskazanie podstawy etymologicznej terminu pozwalałoby dostrzec dobór transliteracyjny decydujący o ortografii i wymowie terminu w danym języku (zob. np. faleronym vs. falaronym w tabeli 1). Źródłosłów zestawionych terminów i ich transliteracja została ustalona przez autora niniejszego artykułu. 
Tabela 1. TO w języku francuskim i angielskim ${ }^{10}$

\begin{tabular}{|c|c|c|}
\hline Termin & Pochodzenie & $\begin{array}{c}\text { Znaczenie }^{11}+ \\
\text { [istniejący pol. ekwiwalent }{ }^{12} \text { ] }\end{array}$ \\
\hline agoronym (ang.) & gr. òyopó agorá 'plac' & $\begin{array}{l}\text { n. placu (rodz. urbanonimu); [pol. ago- } \\
\text { ronim*] }\end{array}$ \\
\hline agronym $*$ (ang.) & gr. $\alpha \gamma \rho o ́ \varsigma$ agrós 'pole’ & n. pola (rodz. mikrotoponimu) \\
\hline ailuronym* (ang.) & 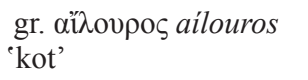 & i. kota \\
\hline americonym * (ang.) & łac. America & $\begin{array}{l}\text { onim właściwy dla amerykańskiego } \\
\text { obszaru }\end{array}$ \\
\hline anémonyme (fr.) & 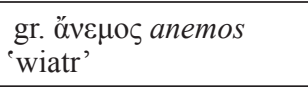 & $\begin{array}{l}\text { n. wiatru, huraganu itp. [pol. anemo- } \\
\text { nim }^{*} \text { ] }\end{array}$ \\
\hline anglonym* (ang.) & łac. Anglia & $\begin{array}{l}\text { onim właściwy dla brytyjskiego obszaru } \\
\text { kulturowego }\end{array}$ \\
\hline apothiconyme* (fr.) & $\begin{array}{l}\text { gr. } \dot{\alpha} \pi \circ \theta \eta \dot{\kappa \eta ~ a p o t e k e ~} \\
\text { 'magazyn, skład' }\end{array}$ & $\begin{array}{l}\text { n. sklepu, zakładu handlowego }[=\text { pol. } \\
\text { emporionim }]\end{array}$ \\
\hline aptronym $*$ (ang.) & $\begin{array}{l}\text { ang. apt (nieuzasad- } \\
\text { nione użycie } r \text { w kon- } \\
\text { strukcji z onym) }\end{array}$ & $\begin{array}{l}\text { n. typu antroponimicznego wskazująca } \\
\text { na określony status nosiciela }\end{array}$ \\
\hline aréonyme* (fr.) & 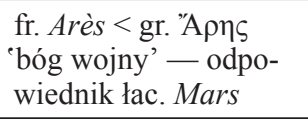 & n. obiektu topograficznego na Marsie \\
\hline arthuronym* (ang.) & ang. Arthur & $\begin{array}{l}\text { i. postaci z legendarnego kręgu rycerzy } \\
\text { króla Artura }\end{array}$ \\
\hline artionym $*$ (ang.) & łac. ars, artis 'sztuka' & n. dzieła artystycznego [= pol. ideonim $]$ \\
\hline astionym (ang.) & 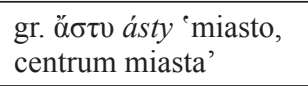 & $\begin{array}{l}\text { n. miasta [pol. astionim } * \text { niezalecany }= \\
\text { pol. urbonim] }\end{array}$ \\
\hline astronyme (fr.) & 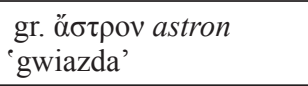 & n. obiektu astralnego [pol. astronim] \\
\hline athlonym* (ang.) & $\begin{array}{l}\text { gr. } \tilde{\alpha} \theta \lambda \text { ov athlon } \\
\text { 'zawody, nagroda' }\end{array}$ & $\begin{array}{l}\text { n. zawodów/mistrzostw i jednocześnie } \\
\text { trofeów sportowych (rodz. faleronimu) }\end{array}$ \\
\hline autonym* (ang.) & 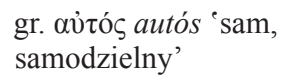 & $\begin{array}{l}\text { autentyczna n. własna osobowa (nie } \\
\text { pseudonim) [pol. autonim* niezalecany] }\end{array}$ \\
\hline balletonym* (ang.) & fr. balet & n. techniki baletowej \\
\hline
\end{tabular}

${ }^{10}$ (ang.) - Room (1996); (fr.) — Dorion \& Poirier (1975).

${ }^{11}$ n. - nazwa, i. - imię.

${ }^{12}$ Gwiazdką oznacza się termin używany sporadycznie, autorski bądź okazjonalny — jako adaptacja propozycji terminologicznych w innym obszarze językowym (głównie czeskim, słowackim lub rosyjskim). 


\begin{tabular}{|c|c|c|}
\hline $\begin{array}{l}\text { bathynyme (fr.) } \\
\text { [recte bathyonyme]/ } \\
\text { bathyonym (ang.) }\end{array}$ & $\begin{array}{l}\text { gr. } \beta \alpha \theta u ́ \varsigma \text { bathus 'głę- } \\
\text { boki' }\end{array}$ & $\begin{array}{l}\text { n. obiektu podmorskiego/na powierzchni } \\
\text { dna morskiego }\end{array}$ \\
\hline biblionym* (ang.) & $\begin{array}{l}\text { gr. } \beta 1 \beta \lambda \text { íov biblion } \\
\text { 'książka' }\end{array}$ & $\begin{array}{l}\text { tytuł książki [pol. biblionim* dysku- } \\
\text { syjny] }\end{array}$ \\
\hline caconym* (ang.) & gr. какó Ł kakós 'zły’ & n. nadana/skonstruowana niepoprawnie \\
\hline campanonym (ang.) & łac. campana 'dzwon' & n. dzwonu [pol. kampanonim ${ }^{13}$ ] \\
\hline cateconym* (ang.) & 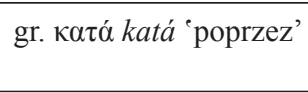 & $\begin{array}{l}\text { n. mieszkańca (np. miasta, regionu) [pol. } \\
\text { katojkonim*] }^{*}\end{array}$ \\
\hline choronyme (fr.) & gr. $\chi \omega ́ \rho \alpha$ chóra 'kraj’ & $\begin{array}{l}\text { nazwa kraju, regionu, większej prze- } \\
\text { strzeni geograficznej }{ }^{14} \text { [pol. choronim] }\end{array}$ \\
\hline $\begin{array}{l}\text { chrématonyme (fr.)/ } \\
\text { chrematonym (ang.) }\end{array}$ & $\begin{array}{l}\text { gr. } \chi \rho \eta ́ \mu \alpha ́, ~ \alpha ́ \tau o \varsigma \\
\text { chrémá, chrématos } \\
\text { 'rzecz, przedmiot, pro- } \\
\text { dukt, przedsięwzięcie' }\end{array}$ & $\begin{array}{l}\text { n. obiektu kultury utworzonego przez } \\
\text { człowieka [pol. chrematonim] }\end{array}$ \\
\hline chrononym (ang.) & 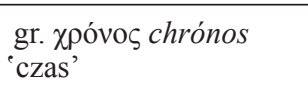 & n. epoki, okresu [pol. chrononim] \\
\hline $\begin{array}{l}\text { citonyme* }^{*} \text { (fr.) } \\
\text { (= komonyme)/como- } \\
\text { nym (ang.) }\end{array}$ & $\begin{array}{l}\text { łac. civitas 'miejsco- } \\
\text { wość'; gr. } \chi \omega \mu \text { kome } \\
\text { 'wies's }\end{array}$ & n. wsi \\
\hline colponym* (ang.) & 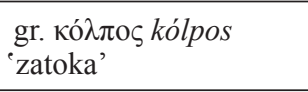 & n. zatoki (rodz. hydronimu) \\
\hline cometonym (ang.) & 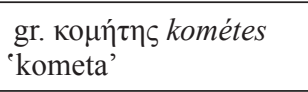 & n. komety \\
\hline cosmonyme (fr.) & gr. кó $\sigma \mu \mathrm{o}$ kosmos & n. obiektu kosmicznego [pol. kosmonim] \\
\hline cynonym* (ang.) & 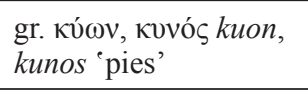 & i. psa [pol. kynonim] \\
\hline dickensonym* (ang.) & ang. Dickens & $\begin{array}{l}\text { n. postaci występującej w utworach } \\
\text { Dickensa }\end{array}$ \\
\hline dignitonym* (ang.) & łac. dignitas 'godność' & $\begin{array}{l}\text { n. nadana np. monarsze jako nawiązanie } \\
\text { do jego zasług }\end{array}$ \\
\hline $\begin{array}{l}\text { documentonym } \\
\text { (ang.) }\end{array}$ & $\begin{array}{l}\text { łac. documentum } \\
\text { 'dokument' }\end{array}$ & $\begin{array}{l}\text { n. dokumentu większej wagi, aktu, trak- } \\
\text { tatu [pol. dokumentonim*] }\end{array}$ \\
\hline dromonym (ang.) & 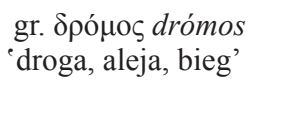 & $\begin{array}{l}\text { n. drogi, traktu lądowego, wodnego, } \\
\text { powietrznego [pol. dromonim*; bliskie } \\
\text { znaczeniu pol. hodonim] }\end{array}$ \\
\hline
\end{tabular}

${ }^{13}$ Zob. Rutkiewicz-Hanczewska (2008).

14 Autorzy słownika francuskiego Dorion \& Poirier (1975) postulowali rozszerzenie zakresu terminu ,choronim" na nazwę każdego obiektu geograficznego, jednak ich propozycja się nie przyjęła, ponieważ takie znaczenie bezdyskusyjnie posiada termin ,toponim”. 


\begin{tabular}{|c|c|c|}
\hline drymonym (ang.) & $\begin{array}{l}\text { gr. } \delta \rho v \mu o ́ \varsigma \\
\text { 'las' } \text { 'drymós’ }\end{array}$ & n. lasu [pol. drymonim] \\
\hline ecclesionym (ang.) & 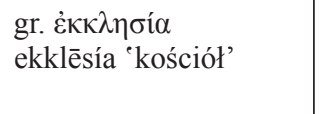 & $\begin{array}{l}\text { n. kościoła, kaplicy (wezwanie) [pol. } \\
\text { eklezjonim* spotykany, na drodze do } \\
\text { przyjęcia] }\end{array}$ \\
\hline econym* (ang.) & $\begin{array}{l}\text { gr. oĩkos oíkos } \\
\text { 'dom’ }\end{array}$ & $\begin{array}{l}\text { n. domu, gospodarstwa, miejsca zamiesz- } \\
\text { kanego (rodz. toponimu/ojkonimu) [pol. } \\
\text { ekonim* niestosowany, ale występujący } \\
\text { w dawniejszych studiach] }\end{array}$ \\
\hline eirgonym* (ang.) & gr. eirgmos 'więzienie' & n. więzienia \\
\hline ergonym (ang.) & gr. ěpyov érgon 'praca' & $\begin{array}{l}\text { n. struktury gospodarczej, spółki, organi- } \\
\text { zacji [pol. ergonim] }\end{array}$ \\
\hline erotonym* (ang.) & 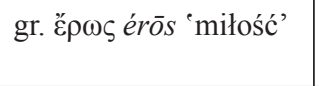 & $\begin{array}{l}\text { n. funkcjonująca jako zwrot do osoby } \\
\text { ukochanej }\end{array}$ \\
\hline euonym* (ang.) & gr. ev̉ eú 'ładny, dobry' & $\begin{array}{l}\text { n. poprawnie skonstruowana, dobrze } \\
\text { brzmiąca, adekwatna }\end{array}$ \\
\hline franconym* (ang.) & łac. Francia & $\begin{array}{l}\text { onim właściwy dla francuskiego obszaru } \\
\text { kulturowego }\end{array}$ \\
\hline genonym* (ang.) & 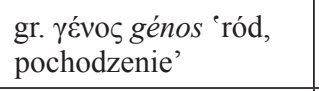 & n. plemienia, rodu (rodz. antroponimu) \\
\hline gephyronym* (ang.) & $\begin{array}{l}\text { gr. } \gamma \varepsilon ́ \varphi v \rho \alpha \\
\text { géphyra 'most' }\end{array}$ & $\begin{array}{l}\text { n. mostu [pol. gefironim/gephyronim* na } \\
\text { drodze do przyjęcia] }]^{15}\end{array}$ \\
\hline germanonym* (ang.) & łac. Germania & $\begin{array}{l}\text { onim właściwy dla niemieckiego obszaru } \\
\text { kulturowego }\end{array}$ \\
\hline gyneconym* (ang.) & gr. $\gamma v v \eta ́$ gynē 'kobieta’ & $\begin{array}{l}\text { n. osobowa męska wywodzona od imie- } \\
\text { nia lub nazwiska kobiety [= pol. metro- } \\
\text { nim*; metronimikum] }\end{array}$ \\
\hline $\begin{array}{l}\text { hélonyme* (fr.)/helo- } \\
\text { nym* (ang.) }\end{array}$ & gr. ć̉os elos 'bagno’ & n. bagna, terenu podmokłego \\
\hline hemeronym* (ang.) & 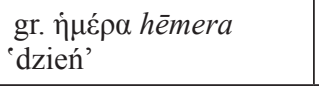 & n./tytuł gazety/dziennika \\
\hline heortonym (ang.) & 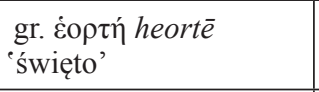 & $\begin{array}{l}\text { n. święta, festiwalu, uroczystości [pol. } \\
\text { heortonim] }\end{array}$ \\
\hline hipponym* (ang.) & gr. í $\pi \pi \mathrm{o}$ hippos 'koń' & imię konia \\
\hline hispanonym* (ang.) & łac. Hispania & $\begin{array}{l}\text { onim właściwy dla hiszpańskiego } \\
\text { obszaru kulturowego }\end{array}$ \\
\hline hymnonym* (ang.) & gr. v̌ $\mu$ vo s hýmnos & n. hymnu \\
\hline
\end{tabular}

${ }^{15}$ Zob. Kowalik (2020). 


\begin{tabular}{|c|c|c|}
\hline iatreionym* (ang.) & $\begin{array}{l}\text { gr. } \tau \text { ò } i \bar{\alpha} \tau \rho \varepsilon i ̃ o v \text { tò } \\
\text { iātreîon 'szpital' }\end{array}$ & n. szpitala/ośrodka medycznego \\
\hline ideonym (ang.) & $\begin{array}{l}\text { gr. i̊źa idéa 'myśl, } \\
\text { pomysł' }\end{array}$ & $\begin{array}{l}\text { n. wytworu myśli ludzkiej (powszech- } \\
\text { nie: n. dzieła/ utworu artystycznego) [pol. } \\
\text { ideonim] }\end{array}$ \\
\hline insulonym* (ang.) & łac. insula 'wyspa' & n. wyspy [= pol. nesonim $]$ \\
\hline italonym* (ang.) & łac. Italia & $\begin{array}{l}\text { onim właściwy dla włoskiego obszaru } \\
\text { kulturowego }\end{array}$ \\
\hline $\begin{array}{l}\text { ktématonyme* (fr.)/ }^{*} \\
\text { ctematonym* (ang.) }\end{array}$ & $\begin{array}{l}\text { gr. } \kappa \tau \tilde{\eta} \mu \alpha \text { ktema 'włas- } \\
\text { ność, mienie, nieru- } \\
\text { chomość, posiadłość' }\end{array}$ & $\begin{array}{l}\text { n. rzeczy, przedmiotu, obiektu handlo- } \\
\text { wego [pol. *ktematonim] }\end{array}$ \\
\hline $\begin{array}{l}\text { limnonyme (fr.)/lim- } \\
\text { nonym (ang.) }\end{array}$ & $\begin{array}{l}\text { gr. } \lambda i ́ \mu v \eta \text { limnē } \\
\text { 'jezioro’ }\end{array}$ & $\begin{array}{l}\text { n. jeziora (rodz. hydronimu) [pol. lim- } \\
\text { nonim] }\end{array}$ \\
\hline $\begin{array}{l}\text { littonyme (fr.)/lito- } \\
\text { nym (ang.) }\end{array}$ & łac. litus 'brzeg' & $\begin{array}{l}\text { n. miejsca/przestrzeni przybrzeżnej, } \\
\text { odcinka terenu w linii brzegowej akwenu } \\
\text { [pol. litoralonim } * \text { ] }\end{array}$ \\
\hline logonim* (ang.) & 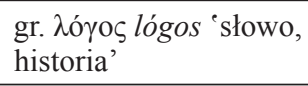 & tytuł utworu literackiego \\
\hline machonym* (ang.) & 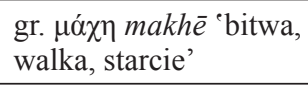 & n. okrętu wojennego \\
\hline mansionym* (ang.) & $\begin{array}{l}\text { łac. mansio 'rezyden- } \\
\text { cja, dom' }\end{array}$ & $\begin{array}{l}\text { n. rezydencji szlacheckiej, posiadłości } \\
\text { historycznej, zamku itp. }\end{array}$ \\
\hline marsionym* (ang.) & łac. Mars & $\begin{array}{l}\text { n. obiektu, przestrzeni na powierzchni } \\
\text { Marsa }\end{array}$ \\
\hline meteoronym* (ang.) & gr. $\mu \varepsilon \tau \varepsilon ́ \omega \rho o$ metéoro & n. meteoru \\
\hline mnemonym* (ang.) & 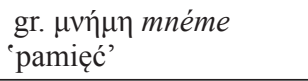 & n. pomnika, monumentu, memoriału \\
\hline museonym* (ang.) & $\begin{array}{l}\text { gr. Movøeĩov } \\
\text { Mouseîon 'świątynia } \\
\text { muz' }\end{array}$ & n. muzeum \\
\hline musiconym* (ang.) & 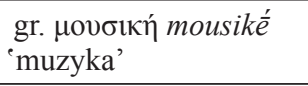 & n. zespołu muzycznego \\
\hline musonym* (ang.) & 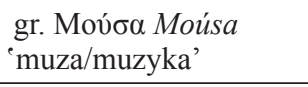 & n. utworu muzycznego \\
\hline $\begin{array}{l}\text { mythonyme (fr.)/ } \\
\text { mythonym (ang.) }\end{array}$ & gr. $\mu$ ṽ $\theta$ o mýthos 'mit' & $\begin{array}{l}\text { n. bytu, miejsca lub zjawiska mitologicz- } \\
\text { nego [pol. mitonim] }\end{array}$ \\
\hline nautonym* (ang.) & $\begin{array}{l}\text { gr. vav́s naús 'łódź, } \\
\text { statek' }\end{array}$ & n. łodzi, statku \\
\hline necronym* (ang.) & 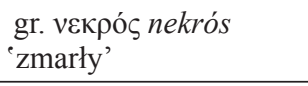 & n. cmentarza \\
\hline oceanonym $*$ (ang.) & 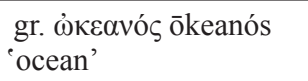 & n. oceanu \\
\hline
\end{tabular}




\begin{tabular}{|c|c|c|}
\hline $\begin{array}{l}\text { odonyme (fr.)/hodo- } \\
\text { nyme (fr.) }\end{array}$ & $\begin{array}{l}\text { gr. óó́ } \\
\text { hodós 'droga' }\end{array}$ & $\begin{array}{l}\text { n. ulicy, drogi, traktu komunikacyjnego } \\
\text { [pol. hodonim] }\end{array}$ \\
\hline paponym* (ang.) & $\begin{array}{l}\text { łac. papa 'biskup, } \\
\text { papież' }\end{array}$ & i. papieskie \\
\hline paradeisonym (ang.) & $\begin{array}{l}\text { gr. } \pi \alpha \rho \alpha ́ \delta \varepsilon 1 \sigma o \varsigma \\
\text { parádeisos 'raj, ogród' }\end{array}$ & n. parku, ogrodu, miejsca rekreacji \\
\hline $\begin{array}{l}\text { pélagonyme (fr.)/ } \\
\text { pelagonym (ang.) }\end{array}$ & $\begin{array}{l}\text { gr. } \pi \varepsilon ́ \lambda \alpha \gamma o \varsigma \\
\text { pélagos 'morze' }\end{array}$ & $\begin{array}{l}\text { n. morza, przestrzeni morskiej [pol. pela- } \\
\text { gialonim }^{*} \text { ] }\end{array}$ \\
\hline $\begin{array}{l}\text { phaleronym (ang.) } \\
\text { [recte phalaronym] }\end{array}$ & $\begin{array}{l}\text { gr. } \varphi \alpha ́ \lambda \alpha \rho o v, 1 . m n . \\
\text { pó } \lambda \alpha \rho \alpha \text { phálaron, } \\
\text { phálera 'falera, medal' }\end{array}$ & n. medalu [pol.faleronim, falaronim] \\
\hline poetonym* (ang.) & 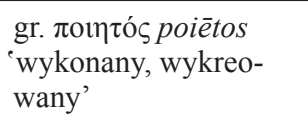 & n. literacka [pol. poetonim*] \\
\hline poleterionym* (ang.) & $\begin{array}{l}\text { gr. } \pi \omega \lambda \eta \tau \text { ' } \rho 10 v \\
\text { polētērion 'sklep, tar- } \\
\text { gowisko' }\end{array}$ & n. sklepu, miejsca targowego \\
\hline polisonyme* (fr.) $^{*}$ & 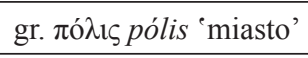 & n. miasta [pol. urbonim] \\
\hline poreionym (ang.) & 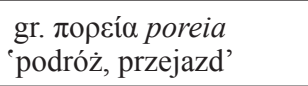 & $\begin{array}{l}\text { n. linii komunikacyjnej, środka/trasy } \\
\text { transportu [pol. porejonim] }\end{array}$ \\
\hline $\begin{array}{l}\text { potamonyme (fr.)/ } \\
\text { potamonym (ang.) }\end{array}$ & $\begin{array}{l}\text { gr. } \pi \text { o } \alpha \alpha \mu \text { ó } \varsigma \\
\text { potamós 'rzeka' }\end{array}$ & $\begin{array}{l}\text { n. wód płynących (np. rzek) [pol. pota- } \\
\text { monim] }\end{array}$ \\
\hline pragmatonym (ang.) & $\begin{array}{l}\text { gr. } \pi \rho \tilde{\alpha} \gamma \mu \alpha \text { pragma } \\
\text { rzecz, obiekt, czyn' }\end{array}$ & $\begin{array}{l}\text { n. obiektu użytkowego [pol. pragmato- } \\
\text { nim }^{*} \text { ] }\end{array}$ \\
\hline $\begin{array}{l}\text { programmonym* } \\
\text { (ang.) }\end{array}$ & $\begin{array}{l}\text { gr. } \pi \rho o ́ \gamma \rho \alpha \mu \mu \alpha \\
\text { prógramma 'program' }\end{array}$ & n. programu TV lub radiowego \\
\hline $\begin{array}{l}\text { régionyme* (fr.)/ } \\
\text { regionym* (ang.) }\end{array}$ & łac. regio 'region' & n. regionu \\
\hline russonym* (ang.) & łac. średn. Russia & $\begin{array}{l}\text { onim właściwy dla rosyjskiego obszaru } \\
\text { kulturowego }\end{array}$ \\
\hline satellonym* (ang.) & łac. satelles 'satelita' & n. satelity \\
\hline scholionym* (ang.) & $\begin{array}{l}\text { gr. } \sigma \chi 0 \lambda \eta ́ ~ s k h o l e \bar{~} \\
\text { 'szkoła, wolny czas' }\end{array}$ & n. szkoły, uczelni \\
\hline $\begin{array}{l}\text { séléonyme }(\mathrm{fr} .) / \text { sele- } \\
\text { nonym (ang.) }\end{array}$ & $\begin{array}{l}\text { gr. } \Sigma \varepsilon \lambda \eta ́ v \eta \\
\text { Seléne 'Księżyc' }\end{array}$ & $\begin{array}{l}\text { n. miejsca lub struktury topograficznej na } \\
\text { powierzchni Księżyca [pol. selenonim* }\end{array}$ \\
\hline $\begin{array}{l}\text { shakespearonym* } \\
\text { (ang.) }\end{array}$ & ang. Shakespeare & $\begin{array}{l}\text { n. własna pochodząca z utworów } \\
\text { Szekspira }\end{array}$ \\
\hline sideronym* (ang.) & $\begin{array}{l}\text { łac. sidus, sideris } \\
\text { 'gwiazda' }\end{array}$ & n. gwiazdy \\
\hline speleonym (ang.) & $\begin{array}{l}\text { gr. } \sigma \pi \hat{\eta} \lambda \alpha \text { เov spēleaion } \\
\text { jaskinia’ }\end{array}$ & $\begin{array}{l}\text { n. jaskini, otwartych przestrzeni pod- } \\
\text { ziemnych [pol. speleonim] }\end{array}$ \\
\hline
\end{tabular}




\begin{tabular}{|c|c|c|}
\hline stadionym* (ang.) & $\begin{array}{l}\text { gr. } \sigma \tau \alpha ́ \delta \text { iov stadion } \\
\text { 'stadion' }\end{array}$ & n. stadionu, bieżni itp. \\
\hline stathmonym* (ang.) & $\begin{array}{l}\text { gr. } \sigma \tau \alpha \theta \mu \text { ó } \text { stathmos } \\
\text { 'stacja, przystanek' }\end{array}$ & $\begin{array}{l}\text { n. stacji/przystanku, dworca, lądowiska, } \\
\text { lotniska }\end{array}$ \\
\hline sympaisonym* (ang.) & $\begin{array}{l}\text { gr. } \sigma 0 \mu \pi \alpha i \zeta c 1 v \text { sympai- } \\
\text { zein 'grać razem' }\end{array}$ & n. drużyny/zespołu sportowego \\
\hline syssitionym* (ang.) & $\begin{array}{l}\text { gr. } \sigma v \sigma \sigma i ́ \tau 1 o v \text { syssition } \\
\text { 'jadalnia, lokal gastro- } \\
\text { nomiczny’ }\end{array}$ & n. restauracji, baru, karczmy itd. \\
\hline tagmonym* (ang.) & 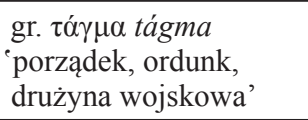 & n. grup wojskowych, pułków, armii itd. \\
\hline teichonym* (ang.) & $\begin{array}{l}\text { gr. } \tau \varepsilon i \tilde{o} \text { os teikhos 'for- } \\
\text { tyfikacja, mur, zamek' }\end{array}$ & n. zamku, fortyfikacji \\
\hline teramnonym* (ang.) & $\begin{array}{l}\text { gr. } \tau \varepsilon ́ p \alpha \mu v o v \text { teramnon } \\
\text { 'pokój, izba' }\end{array}$ & n. pokoju, auli, komnaty \\
\hline theatronym (ang.) & $\begin{array}{l}\text { gr. } \theta \dot{\varepsilon} \alpha \tau \rho o v \text { theatron } \\
\text { 'teatr' }\end{array}$ & n. teatru, grupy teatralnej \\
\hline urbanonym (ang.) & łac. urbanus 'miejski' & $\begin{array}{l}\text { n. obiektu w topografii miejskiej: dziel- } \\
\text { nicy, ulicy, placu, parku, budynku, mostu, } \\
\text { kościoła itd. [pol. urbanonim] }\end{array}$ \\
\hline vulcanonyme (fr.) & $\begin{array}{l}\text { łac. Vulcanus 'imię } \\
\text { rzymskiego boga } \\
\text { ognia' }\end{array}$ & $\begin{array}{l}\text { n. wulkanu [spotykany pol. wulkanonim* } \\
\text { nieprzyjęty] }\end{array}$ \\
\hline xenonym* (ang.) & $\begin{array}{l}\text { gr. 乌́vos xenos 'gość, } \\
\text { obcy' }\end{array}$ & $\begin{array}{l}\text { n. hotelu lub innego obiektu użyteczno- } \\
\text { ści publicznej }\end{array}$ \\
\hline
\end{tabular}

Tabela 2. TO w języku włoskim ${ }^{16}$

\begin{tabular}{|c|c|c|}
\hline Termin & Pochodzenie & Znaczenie + [ewent. pol. ekwiwalent] \\
\hline ampelonimo [15] & $\begin{array}{l}\text { gr. 'A } \mu \pi \varepsilon \lambda \mathrm{\alpha} \text { Ampelos } \\
\text { 'mitologiczne uoso- } \\
\text { bienie winorośli/wina' }\end{array}$ & $\begin{array}{l}\text { n. wina (rodz. chrematonimu) [pol. eno- } \\
\text { nim] }\end{array}$ \\
\hline aracnonimo $^{*}[18]$ & 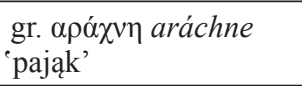 & n. gatunkowa pająka \\
\hline astionimo [2] & 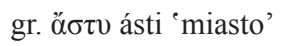 & n. miejsca fortyfikowanego \\
\hline
\end{tabular}

${ }^{16}$ Odpowiedniki odniesień źródłowych: [1] Caffarelli, Gagliardi (2018); [2] Borghi (2020); [3] Borghi (2021); [4] Bracchi (2013); [5] Caffarelli (2005); [6] Caffarelli (2016); [7] Caffarelli (2018a); [8] Caffarelli (2018b); [9] Caffarelli (2018c); [10] Caffarelli (2018d); [11] Caffarelli (2018e); [12] Caffarelli (2018f); [13] Caffarelli (2018g); [14] Caffarelli (2021); [15] Costantini (2011); [16] Gałkowski (2020a); [17] Gałkowski (2019); [18] Mussano (2019); [19] Caffarelli (2018h); [20] Terrusi (2021); [21] Finco (2019). 


\begin{tabular}{|c|c|c|}
\hline avonimico $^{*}[1]$ & $\begin{array}{l}\text { wł. avo < łac. avus } \\
\text { 'przodek' }\end{array}$ & $\begin{array}{l}\text { n. osobowa pochodząca od imienia/ } \\
\text { nazwiska przodka, np. dziadka }\end{array}$ \\
\hline boonimo* $^{[1]}$ & $\begin{array}{l}\text { łac. bovem 'wół'; wł. } \\
\text { bovino 'wołowy' }\end{array}$ & n. rasy bydła \\
\hline comonimo [2] & 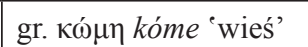 & n. wsi \\
\hline cromonimo $[1]$ & $\begin{array}{l}\text { gr. } \chi \rho \tilde{\omega} \mu \alpha, \chi \rho \omega ́ \mu \alpha \tau o \varsigma \\
\text { khrōma, khrōmatos } \\
\text { 'kolor' }\end{array}$ & n. koloru [pol. chromonim] \\
\hline dendronimo $[21]$ & 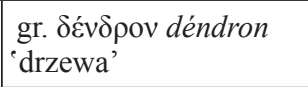 & $\begin{array}{l}\text { n. indywidualna drzewa [pol. dendro- } \\
\text { nim] }\end{array}$ \\
\hline dossonimo $^{*}[1]$ & $\begin{array}{l}\text { gr. } \delta o ́ \xi \alpha \text { dóxa 'opinia, } \\
\text { przekonanie, pogląd' }\end{array}$ & $\begin{array}{l}\text { rodz. pseudonimu motywowanego opi- } \\
\text { nią społeczną, polityczną, ideologiczną } \\
\text { o nosicielu }\end{array}$ \\
\hline emeronimo [20] & 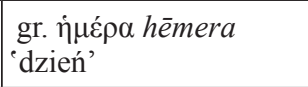 & n. dnia dedykowanego określonej idei \\
\hline farmaconimo [6] & wł. farmaco 'lek' & n. handlowa leku [pol.farmakonim] \\
\hline gefironimo* $[2]$ & $\begin{array}{l}\text { gr. } \gamma \dot{\varepsilon} \varphi \bar{v} \rho \alpha ̆ \text { géfỹră } \\
\text { 'most' }\end{array}$ & n. mostu \\
\hline glottonimo [1], [9] & $\begin{array}{l}\text { gr. } \gamma \lambda \tilde{\omega} \tau \tau \alpha \text { glótta } \\
\text { ‘język’ }\end{array}$ & n. języka \\
\hline idionimo* $[1]$ & $\begin{array}{l}\text { gr. '̊́oł idios 'własny, } \\
\text { prywatny, swoisty' }\end{array}$ & n. osobowa indywidualna/imię \\
\hline ilaronimo* $^{[4]}$ & $\begin{array}{l}\text { łac. hilarus < gr. } \\
\text { i } \lambda \alpha \rho o ́ \varsigma \text { 'wesoły, } \\
\text { radosny, pogodny' }\end{array}$ & $\begin{array}{l}\text { n. fantazyjna o zabawnym zabarwieniu } \\
\text { (w odniesieniu do przypadkowych kon- } \\
\text { strukcji tworzących z zestawienia 'imię } \\
\text { i nazwisko' humorystyczne wyrażenia; } \\
\text { w tej kategorii także takie metanazwy } \\
\text { motywowane retorycznie, jak: zeugo- } \\
\text { nimo*, aritmonimo*, antiballonimo*, } \\
\text { sintagmonimo*, simballonimo*, gamo- } \\
\text { nimo*, anfibolonimo*, copronimo*17 }\end{array}$ \\
\hline ionimo* $^{[3]}$ & $\begin{array}{l}\text { gr. iós iós ‘wirus' } \\
\text { (ekw. łac. uīrŭs) }\end{array}$ & n. gatunkowa wirusa \\
\hline ipponimo* $[22]$ & gr. í $\pi$ os hippos 'koń' & i. konia/n. rasy koni \\
\hline ittionimo* $^{[1]}$ & gr. ix $\theta u ́ s$ ichtýs 'ryba' & n. gatunkowa ryb \\
\hline kinematonimo* $^{*}[10]$ & niem. Kino & n. kina \\
\hline koinonimo* $[1]$ & $\begin{array}{l}\text { gr. koinônia 'wspól- } \\
\text { nota' }\end{array}$ & n. wspólnoty, grupy społecznej \\
\hline
\end{tabular}

${ }^{17}$ Szczegółowe objaśnienia zob. Bracchi (2013). 


\begin{tabular}{|c|c|c|}
\hline $\begin{array}{l}\text { letteraronimo* }[7] \text {, } \\
{[16]}\end{array}$ & $\begin{array}{l}\text { adaptacja słow. } \\
\text { literáronymum }\end{array}$ & n. literacka (termin dyskusyjny) \\
\hline ludonimo* $[12]$ & $\begin{array}{l}\text { łac. ludus 'gra, } \\
\text { zabawa' }\end{array}$ & $\begin{array}{l}\text { n. gry (szczególnie w funkcji n. handlo- } \\
\text { wych) }\end{array}$ \\
\hline $\begin{array}{l}\text { marchionimo }[1], \\
{[19]}\end{array}$ & $\begin{array}{l}\text { wł. marchio 'znak } \\
\text { (handlowy)' }\end{array}$ & $\begin{array}{l}\text { n. handlowa/firmowa/n. marki [pol. mar- } \\
\text { konim }^{*} \text { ] }\end{array}$ \\
\hline merceonimo* $^{[1]}$ & w1. merce 'towar' & n. towaru/produktu \\
\hline nanonimo* $[5]$ & $\begin{array}{l}\text { wł. nano 'krasnolu- } \\
\text { dek' }\end{array}$ & n. fantazyjna/i. krasnoludka \\
\hline naonimo [1], [11] & $\begin{array}{l}\text { gr. voúc naús 'statek, } \\
\text { łódź’ }\end{array}$ & n. statku, łodzi \\
\hline necronimo [1] & 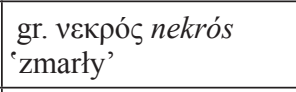 & $\begin{array}{l}\text { n. osobowa pochodząca od imienia } \\
\text { osoby zmarłej }\end{array}$ \\
\hline nesonimo $[1]$ & $\begin{array}{l}\text { gr. víøo̧ nếsos } \\
\text { 'wyspa’ }\end{array}$ & n. wyspy [pol. nesonim] \\
\hline ornitonimo* $^{*}[1],[14]$ & 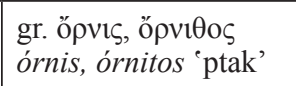 & $\begin{array}{l}\text { n. nadana pojedynczemu ptakowi lub } \\
\text { gatunkowi ptaków }\end{array}$ \\
\hline pedonimo* [8] & $\begin{array}{l}\text { nawiązanie do wł. } \\
\text { pedologia 'glebo- } \\
\text { znawstwo' (konfuzja } \\
\text { dotyczy podstawy gr. } \\
\pi \varepsilon ́ \delta \text { '́ pédon 'gleba’ } \\
\text { kojarzonej z gr. } \pi \alpha i ̃ \varsigma \\
\text { pâis 'dziecko') }\end{array}$ & $\begin{array}{l}\text { n. struktury terenu cechującej się okreś- } \\
\text { lonym gatunkiem gleby }\end{array}$ \\
\hline pirgonimo [17] & $\begin{array}{l}\text { gr. } \pi u ́ \rho \gamma o s \text { pýrgos } \\
\text { 'wieża' }\end{array}$ & n. wieży \\
\hline pokemonimo* [13] & $\begin{array}{l}\text { od nazwy Pokemon } \\
\text { (postać w japońskiej } \\
\text { serii gry video) }\end{array}$ & i. pokemona \\
\hline poleonimo $[1]$ & $\begin{array}{l}\text { gr. } \pi \text { ó } \lambda \mathrm{s}, \pi \text { ó } \lambda \varepsilon \omega \varsigma \\
\text { pólis, póleos 'miasto' } \\
\text { również 'wspólnota } \\
\text { obywateli' }\end{array}$ & n. miejsca zasiedlonego \\
\hline silvonimo $[15]$ & łac. sŭlva 'las' & n. lasu, boru itp. [= pol. drymonim] \\
\hline singenionimo $[1]$ & 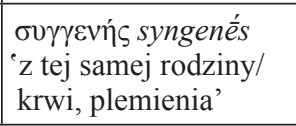 & n. krewnego \\
\hline socionimo $[1]$ & $\begin{array}{l}\text { łac. socialis 'spo- } \\
\text { łeczny' }\end{array}$ & $\begin{array}{l}\text { n. miejsca użyteczności publicznej/spo- } \\
\text { łecznej (np. szpital, szkoła, dworzec itp.) }\end{array}$ \\
\hline tecnonimo* $[1]$ & $\begin{array}{l}\text { gr. } \tau \dot{\kappa} \kappa v o v \text { téknon } \\
\text { 'dziecko’ }\end{array}$ & n. osobowa od imienia dziecka/syna \\
\hline terionimo* $[1]$ & 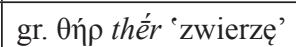 & n. zwierzęcia \\
\hline
\end{tabular}




\section{OMÓWIENIE ZBIORU ANGIELSKICH, FRANCUSKICH I WŁOSKICH METANAZW}

Zestawione zbiory TO w języku francuskim, angielskim i włoskim w większości przypadków można uznać za osobliwe, tworzone ze względu na pojawiające się potrzeby terminologiczne lub na zasadzie rozwinięcia określonych serii. Szczególną uwagę przyciągają te $\mathrm{z}$ nich, które okazują się zupełnie zbędne lub tworzone były w sposób dostosowany do wyobrażeń autorskich, ale nieprzyjmowane przez innych specjalistów, w tym przede wszystkim onomastów. Najwięcej kontrowersji wzbudzają propozycje Adriana Rooma (1996), które spotykały się i spotykają z krytyką innych ekspertów, głównie tych zajmujących się terminologią onomastyczną (zob. Zgusta, 1998; Caffarelli, 1999), ale należy też zauważyć, że jest to zbiór inspirujący do rozważań nad „terminologizacją” konceptów zjawisk obserwowanych w przestrzeni onimicznej.

Do najbardziej kontrowersyjnych wśród propozycji Rooma należą nazwy nazw własnych występujących na danym obszarze terytorialno-językowym, jak americonyms, anglonyms, germanonyms lub italonyms, które thumaczyć by trzeba jako „amerykanonimy”, ,anglonimy”, ,germanonimy”, ,italonimy”. Sama próba translacji zdradza ich osobliwość. Bardziej jednak zastanawia uogólnienie sugerowane wykorzystanym etnonimem dla desygnowania zbiorów nazw własnych w danym obszarze, które zwykło się określać jako „onomastykon/onimia amerykańska”, ,onomastykon/onimia angielska”, „onomastykon/onimia niemiecka” itd.

Podobnie zdumienie budzą terminy Rooma odnoszone z kolei do onomastykonów w utworach wybranego pisarza (skądinąd dlaczego tego, a nie innego?), jak dickensonyms czy shakespearionyms, oraz rzeczywistości w przykładowej opowieści literacko-legendarnej, jak arthuronyms. Zadać by tu można pytanie retoryczne, jak wiele tego rodzaju TO musiałoby zaistnieć, gdyby przyjęto tego rodzaju model terminologiczny za potrzebny i obowiązujący.

Najbardziej jednak należy zważać na tworzenie terminów ewidentnie nieuzasadnionych, niejednoznacznych i niepoprawnych. W ich ocenie można by wręcz użyć jednego z domniemanych TO ukutych przez samego Rooma, a mianowicie caconyms, bowiem kuriozalnie wyglądają bowiem takie formy jak aptronym (twór ze zbędnym $r$ w śródgłosie, zapewne nazbyt swobodnie kojarzonym z tą głoską $\mathrm{w}$ terminie antroponim), a także erotonym, paponym, sympaisonym, syssitionym czy też xenonim i wiele innych (zob. tabelę 1).

Różnorodność propozycji Rooma w założeniu była być może czymś zapowiadającym się obiecująco, jednak autor padł ofiarą własnej fantazji i nadmiernej niefrasobliwości, tworząc wiele wynotowanych tutaj i innych terminów w swoim słowniku na bazie nieprzemyślanych w wielu wypadkach podstaw greckich lub łacińskich. 
Wypada jednak zauważyć, że w glosariuszu angielskiego leksykografa ${ }^{18}$ znalazły się także terminy odtwarzające dostrzeżone w innych źródłach wzory, co potwierdzałyby istniejące ekwiwalenty m.in. w języku francuskim, wynotowane z glosariusza toponomastycznego Doriona i Poiriera (1975).

Dla wielu TO zamieszczonych w słowniku Rooma znajdujemy potwierdzenie w innych opracowaniach i źródłach terminologii używanej w onomastyce. Nie można przy tym wykluczyć, że niektóre z haseł terminologicznych upowszechniły się właśnie dzięki tej publikacji. Dotyczyłoby to np. terminu urbanonim (nazwa miejsca lub obiektu miejskiego), któremu Room nadał powszechnie podzielaną obecnie definicję, odpowiednio konfrontowaną z paronimicznym urbonimem (nazwa miasta).

Mniej kontrowersji w ocenie proponowanych terminów budzi słownik autorów kanadyjskich. Co więcej, glosariusz Doriona i Poiriera (1975) stanowić mógł podstawę lub pracę o szerszym wymiarze leksykograficznym, powstałą w efekcie ustalania terminologii toponomastycznej, która została przedstawiona jako zestandaryzowana w kolejnych wydaniach słownika UNGEGN (zob. GTSGN) ${ }^{19}$.

Jak już wspomniano, francuski słownik czerpał inspiracje m.in. z ujęć proponowanych nieco wcześniej w źródłach słowiańskich, będących podstawą licznych propozycji terminologicznych nawiązujących formalnie do języków klasycznych. Dzięki Dorionowi i Poirierowi (1975) weszły do globalnego użytku takie terminy, jak: choronim, hodonim, oronim, macrotoponim, microtoponim, potamonim i wiele innych. W większości wypadków nie byłoby podstaw, aby je kwalifikować jako „osobliwe”, gdyby nie to, że ich definicje mogą się różnić od innych ujęć tego samego pojęcia (zob. np. próbę zastąpienia terminu toponim przez choronim). Podejście onomazjologiczne w tworzeniu TO bywa w tej sytuacji zakłócane, co w konsekwencji prowadzi do desygnowania odmiennych obiektów lub innej wizji kontekstualnej tej samej klasy obiektów (np. rozumienia przez mikro- i makrotoponimy nazw obiektów toponimicznych postrzeganych przez skalę ich wielkości fizycznej, nie zaś zasięgu w użytku komunikacyjnym, por. wyżej).

Problem osobliwych definicji dotyczy zresztą kolejno rozpatrywanych źródeł włoskich, które w wielu wypadkach mają charakter opracowań poddających pod dyskusję przedostającą się na grunt włoski onomastyczną terminologię międzynarodową. Większość tych publikacji jest autorstwa Enza Caffarellego oraz Guida Borghiego ${ }^{20}$, którzy na łamach czasopisma „Rivista Italiana di Onomastica”,

${ }^{18}$ Znanego z publikowania w latach 90. XX wieku wielu tematycznych słowników i kompendiów o charakterze naukowym lub popularnonaukowym, niekiedy posądzanego o tendencje grafomańskie, zob. https://www.biblio.com/room-adrian/author/76029 (dostęp: 29.04.2021).

${ }_{19} \mathrm{Na}$ temat specyfiki terminologii UNGEGN oraz jej różnorodności zob. Wolnicz-Pawłowska (2017) oraz Borghi, Caffarelli (2018).

${ }^{20} \mathrm{~W}$ bibliografii podano ich wybór. 
przy współudziale innych autorów, prowadzą dział pt. „Osservatorio terminologico” („Obserwatorium terminologiczne”).

Uwagę włoskich onomastów przykuł np. termin literáronymum, utworzony w języku słowackim przez Pavla Odaloša (2012). W opinii E. Caffarellego (2018a) jest to termin motywowany nieprawidłowo dobraną podstawą. Jednocześnie włoski onomasta adaptuje go do języka włoskiego przy użyciu ekwiwalentu letteraroni$m o$, który przyprawia o jeszcze większą konfuzję niż pierwotny wzór słowacki ${ }^{21}$.

Zestawienie włoskich TO pozwala zauważyć kolejne własności włoskiej terminologii onomastycznej, np. w podejściu do tak istotnej kwestii, jaką jest uznawanie danego zbioru nazw za onimię. Dotyczy to nazw gatunkowych organizmów, jak np. aracnonimo (n. pająków), boonimo (n. bydła), ittionimo (n. ryb), ornitonimo (n. ptaków) czy powstały niedawno ionimo (n. wirusów). Dodatkową okolicznością wprowadzającą nieostrość tych terminów jest jednoczesne ich używanie w przypadku nazw/imion pojedynczych egzemplarzy danej klasy, rasy itd. bytów żyjących, na zasadzie zaadaptowanego do włoszczyzny cinonimo (imię psa) lub krytykowanego w świetle rozpatrywanej wyżej propozycji Rooma ailuronimo (imię kota, zob. Caffarelli, 1999).

Podejście włoskich onomastów do terminologii onomastycznej można określić jako racjonalne, ale w niektórych obszarach należy odnotować dość swobodną kreatywność ad hoc. Zazwyczaj jest to wynik wykorzystania potencjału słowa dla podkreślenia efektu osiąganego przez obrazowe włączanie do metanazwy leksemu przejrzyście i wprost określającego specyficzny obiekt w przestrzeni artystycznej, literackiej, medialnej, ludycznej.

Na uwagę w tym względzie zasługują takie propozycje terminologiczne, jak: ludonimo, nanonimo, pokemonimo czy też ilaronimo i seria odmian tegoż (właściwe definicje w tabeli 2). Można by je uznać za dopuszczalne okazjonalizmy autorskie TO, jednak powstaje pytanie, czy takie jednorazowe i sporadyczne ich użycie jest w nauce dopuszczalne. Trudno tu jednak wyobrazić sobie powstrzymanie kreatorów autorskiej terminologii przed zastosowaniem licentia poetica, ponieważ proponowane terminy mają teoretyczny potencjał w opisie zaobserwowanych zjawisk językowo-kulturowych. Prób tego typu odnotowuje się w onomastyce dziesiątki i należałoby im poświęcić szersze opracowanie.

Podsumowując omówienie włoskiej części analizowanego korpusu metanazw, należy jeszcze stwierdzić, że w wielu przypadkach są one wypadkową uważnej obserwacji i dostosowania istniejących już w innych obszarach terminów onomastycznych, np. przyjętych przez włoskich badaczy takich konceptów i odpowiadających im określeń terminologicznych, jak crematonimo, cromonimo, nesonimo, pirgonimo.

21 Por. Gałkowski, 2020a; tu modyfikacja adaptowanego terminu na rzecz wł. literaronimo. 
Uznać za trafne i przydatne można też niektóre z zupełnie oryginalnych i potrzebnych propozycji terminologicznych onomastów włoskojęzycznych, jak np. farmaconimo, glottonimo, marchionimo, naonimo, singenionimo. Ich adaptację należy jednak rozważać w kontekście wchłaniających je języków, np. angielskiego, który niekiedy jest „zmuszany” do przyjęcia danego odpowiednika terminologicznego, choćby w streszczeniach publikacji onomastycznych powstających w języku włoskim.

Ostatnią kwestią, którą uznaję za nader istotną w świetle zestawianych zasobów terminologii onomastycznej, są znaczne rozbieżności w stosowaniu terminów zasadniczo tworzonych w jednakowy sposób, a oznaczających według intencji ich autorów odmienne koncepty (por. np. ang. heronym w tabeli $1 \mathrm{i}$ wł. eronimo $\mathrm{w}$ tabeli 2 bądź ang. necronym $\mathrm{w}$ tabeli $1 \mathrm{i}$ wl. necronimo $\mathrm{w}$ tabeli $2^{22}$ ).

\section{ZAKOŃCZENIE}

Podsumowując rozważania na temat osobliwości wśród metanazw i innych terminów włączanych do zasobów uznanej lub nieuznanej terminologii onomastycznej, można przyjąć, że jest to obszar słowotwórczy nie mniej interesujący niż jednostki onimiczne będące obiektem opisu naukowego za pomocą „metanazwowo” tworzonych kreacji leksykalnych. Mają one charakter neologiczny i wyróżniają się na tle ogólnej terminologii językoznawczej, która zdaje się podchodzić do nich z pewną rezerwą, tym bardziej uzasadnioną, że wynikającą z powściągliwości i ostrożności lub nieostrożności samych onomastów.

Stosując jeszcze jeden z terminów używanych akurat na gruncie onomastyki i ogólnie leksykologii włoskiej, można by powiedzieć, że wielu badaczy nazw własnych pod wpływem badanej materii staje się „onomaturgami” (twórcami nazw) we własnej sprawie. Potwierdzić przy tym należy pogląd, że powstająca terminologia onomastyczna w zakresie ,nazw nazw” lub „metanazw”23 ma podstawę onomazjologiczną, która jednak nie zawsze jest potwierdzana adekwatnością definicji/znaczeń nadawanych powstającym lub adaptowanym terminom, co z kolei powoduje nieostrość i niejednoznaczność terminologiczną również na poziomie semazjologicznym.

${ }^{22}$ O rozbieżnościach onomastyczno-terminologicznych między językami i obszarami językowo-kulturowymi zob. Shokhenmayer (2014).

${ }^{23}$ Przez Á. Iglesiasa Ovejero (2017) nazwanych — niejako w wyniku poczucia obowiązku terminotwórczego - „metonimami” (fr. métonymes), co może się z kolei mylić z paronimicznym upodobnieniem do retorycznego terminu metonimia. 


\section{LITERATURA}

Bijak, U. (2019). Polska terminologia onomastyczna. Ku harmonizacji systemu [Polish onomastic terminology. Towards the harmonization of the system]. W: A. Chomová, J. Krško i I. Valentová (red.), Konvergencie a divergencie v propriálnej sfére. 20. slovenská onomastická konferencia. Banská Bystrica 26.-28. júna 2017. Zborník referátov [Convergence and Divergence in the Proprial Sphere. Proceedings of the $20^{\text {th }}$ Slovak Onomastic Conference. Banská Bystrica 26-28 June 2017] (s. 44-52). Bratislava: VEDA Vydavatel'stvo Slovenskej akadémie vied.

Borghi, G. (2020). Ma allora astionimo, comonimo e gefironimo? [So astionimo, comonimo and gefironimo?]. Rivista Italiana di Onomastica, XXVI(1), 466-467.

Borghi, G. (2021). Coronavirus (per Coronouirus o Coroniuirus) e Respirology (per Pnoology) [Coronavirus (for Coronouirus or Coroniuirus) and Respirology (for Pnoology)]. Rivista Italiana di Onomastica, XXVII(1), 388-389.

Borghi, G., Caffarelli, E. (2018). Ma l'ipertrofia terminologica non è una novità [But terminological hypertrophy is nothing new]. Rivista Italiana di Onomastica, XXIV(2), 999-1000.

Borghi, G., Caffarelli, E. (2021). Imprecisioni e abusi in Russia e in Ucraina [Inaccuracies and abuses in Russia and Ukraine]. Rivista Italiana di Onomastica, XXVII(1), 386-387.

Bracchi, R. (2013). Ilaronimi ossia combinazioni curiose di nomi (censimento fantasioso) [Ilaronyms or curious combinations of names (fanciful census)]. Rivista Italiana di Onomastica, XIX(1), 189-198.

Caffarelli, E. (1999). Pragmonimi, ailuronimi e altri nomi di nomi [Pragmonyms, ailuronyms and other names of names]. Rivista Italiana di Onomastica, V(2), 647-648.

Caffarelli, E. (2005). Nanònimi, liste da rifare [Names of dwarfs, lists to be redone]. Rivista Italiana di Onomastica, XI(2), 617-618.

Caffarelli, E. (2016). Per un approccio alla farmaconimia [For an approach to pharmaconymy]. Rivista Italiana di Onomastica, XXII(2), 701-755.

Caffarelli, E. (2018a). E ora spuntano anche i letteraronimi [And now there are also literaronyms]. Rivista Italiana di Onomastica, XXIV(1), 441.

Caffarelli, E. (2018b). Che cos'è un pedonimo? [What is a pedonym?]. Rivista Italiana di Onomastica, XXIV(1), 442.

Caffarelli, E. (2018c). Glottonimi discussi: neerlandese, fiammingo, olandese, belga [Debatable language names: neerlandese, fiammingo, olandese, belga]. Rivista Italiana di Onomastica, XXIV(1), 448-449.

Caffarelli, E. (2018d). Dal kinematonimo all'astronimo (minore) [From kinematonym to (minor) astronym]. Rivista Italiana di Onomastica, XXIV(1), 463.

Caffarelli, E. (2018e). Fiat Argo e Škoda Kodiaq, dal naonimo e dallo zoonimo (denesonimico) [Fiat Argo and Škoda Kodiaq, from naonym to (denesonymic) animal name]. Rivista Italiana di Onomastica, XXIV(1), 464.

Caffarelli, E. (2018f). Ludonimi transonimizzati [Transonymic ludonyms]. Rivista Italiana di Onomastica, XXIV(1), 505-506.

Caffarelli, E. (2018g). Dai videogiochi ecco i pokemonimi [From videogames to pokemonyms]. Rivista Italiana di Onomastica, XXIV(2), 1003.

Caffarelli, E. (2018h). Brand, marca, marchio, marchionimo [Brand, marca, marchio, marchionimo]. Rivista Italiana di Onomastica, XXIV(2), 996-997.

Caffarelli, E. (2021). Ornitonimi come titoli letterari [Ornithonyms as literary titles]. Rivista Italiana di Onomastica, XXVII(1), 427.

Caffarelli, E., Cagliardi, C. (2018). Terminologia onomastica [Onomastic terminology]. Archivio per il vocabolario storico e italiano AVSI, I, 11-54. 
Costantini, E. (2011). Ampelonimia friulana [Friulian ampelonymy]. Rivista Italiana di Onomastica, $X V I I(2), 607-630$

Czopek-Kopciuch, B. (2020). Jeszcze o potrzebie ujednolicenia terminologii onomastycznej [Once more about the need to harmonize onomastic terminology]. W: A. Siwiec, I. Domaciuk-Czarny i M. Kojder (red.), Ze studiów nad nazwami własnymi. Terminologia. Teoria i metodologia badań. Zagadnienia nazwotwórstwa [From the Study of Proper Names. Terminology. Theory and Methodology of Research. The Issues of Name-Formation] (s. 47-54). Lublin: Wydawnictwo UMCS.

Dorion, H. i Poirier, J. (1975). Lexique des termes utiles à l'étude des noms de lieux. Québec: Les Presses de l'Université Laval.

Finco, F. (2019). Dendronimi e dendrotoponimi [Dendronyms and dendrotoponyms]. Rivista Italiana di Onomastica, XXV(1), 432-435.

Gałkowski, A. (2019). I pirgonimi, nomi non marginali nella toponimia italiana [Pirgonyms, nonmarginal names in Italian toponymy]. Rivista Italiana di Onomastica, XXV(1), 233.

Gałkowski, A. (2020a). Literaronimo (slovacco sing. literáronymum, plur. literáronymá) è adeguato all'idea scientifica che rappresenta? [Is literaronym (Slovac sing. literáronymum, plur. literáronymá) appropriate to the scientific idea it represents?]. Rivista Italiana di Onomastica, XXVI(2), 965-966.

Gałkowski, A. (2020b). Rozwój międzynarodowych prac nad terminologią onomastyczną — przegląd ujęć słowiańskich [Development of international works on onomastic terminology: Review of Slavic approaches]. W: A. Siwiec, I. Domaciuk-Czarny i M. Kojder (red.), Ze studiów nad nazwami własnymi. Terminologia. Teoria i metodologia badań. Zagadnienia nazwotwórstwa [From the Study of Proper Names. Terminology. Theory and Methodology of Research. The Issues of Name-Formation] (s. 11-30). Lublin: Wydawnictwo UMCS.

GTSGN = Department of Economic and Social Affairs, Statistics Division, United Nations Group of Experts on Geographical Names (2002). Glossary of Terms for the Standardization of Geographical Names. Glossaire de termes pour la normalisation des noms géographiques et al. New York: United Nations.

Górny, H. (2020). Czy istnieje potrzeba leksykograficznego opracowania terminów antroponomastycznych? [Is there a need for a lexicographic study of anthroponomastic terms?]. Onomastica, 64, 93-106.

Hough, C. (red.). (2016). The Oxford Handbook of Names and Naming. Oxford: Oxford University Press.

Iglesias Ovejero, Á. (2017). Pour une terminologie univoque de la désignation onomastique: Noms de Noms Propres. W: D. Kremer (red.), Onomastik, Bd. 2: Namensysteme im interkulturellen Vergleich (s. 41-57). Berlin-Boston: De Gruyter.

Karaś, M. (1968). W sprawie polskiej terminologii onomastycznej [On the Polish onomastic terminology]. Onomastica, 13, 352-360.

Kowalik, K. (2020). Topograficzno-historyczna geneza nazw własnych krakowskich mostów i innych budowli służących przeprawie [Topographical-historical origins of proper names of bridges and other structures for crossing in Cracow]. Annales Universitatis Paedagogicae Cracoviensis. Studia Linguistica, 15, 131-144. https://doi.org(1)0.24917(2)0831765.15.11.

Mussano, F. (2019). «The Man in Black»: Dall'antroponimo soprannominale all'aracnonimo [«The Man in Black»: Fom supernominal anthroponym to arachnonym]. Rivista Italiana di Onomastica, XXV(1), 447.

Odaloš, P. (2012). Literáronymá v slovenskej literatúre [Literaronyms in Slovak Literature]. Banská Bystrica: Univerzita Mateja Bela.

Odaloš, P. i Vallová, E. (2020). Sústava slovanskej onomastickej terminológie (vznik, existencia, neuralgické miesta, aktualizácia) [The system of Slavic onomastic terminology (origin, existence, trouble points, updating)]. Folia onomastica Croatica, 29, 169-202. 
Pisarek, W. (2021). Nazwy własne? A co to właściwie jest i do czego służy? [Proper names? What exactly is it and what is it for?]. W: M. Rutkowski i A. Hącia (red.), Nazwy własne w języku i spoteczeństwie [Proper Names in Language and Society] (s. 13-21). Olsztyn: Wydawnictwo UWM.

Podolskaâ, N.V. (1970). O razvitii otečestvennoj toponimičeskoj terminologii [On the development of national toponymic terminology]. W: E.M. Pospelov (red.) Razvitie metodov toponimičeskih issledovanij [The Development of Toponymic Research Methods] (s. 46-55). Moskva: Nauka.

Podolskaâ, N.V. ([1978] 1988). Slovar' russkoj onomastičeskoj terminologii [Dictionary of Russian Onomastic Terminology]. Moskva: Nauka.

Ro om, A. (1996). An Alphabetical Guide to the Language of Name Studies. Lanham, MD-London: The Scarecrow Press.

Rutkiewicz-Hanczewska, M. (2008). Kampanonimy jako gatunek nazewniczy [Campanonyms as a naming genre]. Slavia Occidentalis, 65, 107-126.

Rutkowski, M. (2012). Onomastyka a metaonomastyka [Onomastics vs. metaonomastics]. W: I. Łuc i M. Podgłódek (red.), W komunikacyjnej przestrzeni nazw własnych i pospolitych. Księga jubileuszowa dedykowana Profesorowi Robertowi Mrózkowi [In the Communicative Space of Proper and Common Names. Festschrift Dedicated to Professor Robert Mrózek] (s. 317-323). Katowice: Wydawnictwo UŚ.

Shokhenmayer, E. (2014). Terminological discrepancy of modified proper names between English, French, German and Russian. W: J. Tort i Donada \& M. Montagut (red.), Els noms en la vida quotidiana. Actes del XXIV Congrés Internacional d'ICOS sobre Ciències Onomàstiques Names in daily life. Proceedings of the XXIV International Congress of Onomastic Sciences (s. 92-98). Barcelona: Generalitat de Catalunya, Departament de Cultura, Direcció General de Política Lingüística Onomàstica. http://www.gencat.cat/llengua/BTPL/ICOS2011/011.pdf

Svoboda, J. (1960). K slovanské onomastické terminologii [On Slavic Onomastic Terminology]. Zpravodaj Mistopisné komise ČSAV, 1, 273-284. Także w: Slawische Namenforschung (1963), 261-273.

Terrusi, L. (2021). Una data come titolo. Per una fenomenologia degli "emeronimi" come soglie testuali [A date as a title. For a phenomenology of "emeronyms" as textual thresholds]. Rivista Italiana di Onomastica, XXVII(1), 15-30.

Titomanlio, C. (2016). I discendenti di Nearco. L'ipponomastica tra arte e letteratura [The descendants of Nearchus. Horse naming between art and literature]. il Nome nel testo. Rivista internazionale di onomastica letteraria, XVIII, 227-235.

Vidoeski, B. i in. (1983). Osnoven sistem i terminologija na slovenskata onomastika. Osnovnaâ sistema i terminologiâ slavânskoj onomastiki. Grundsystem und Terminologie der slawischen Onomastik. Skopje: Makedonska akademija na naukite i umetnostite.

Wolnicz-Pawłowska, E. (2017). Problemy terminologiczne $w$ działalności UNGEGN [Terminological problems in the work of UNGEGN]. W: P. Piper i V. Kovnović (red.), Slovenska terminologia danas/Slavonic Terminology Today (s. 343-350). Beograd: Srpska akademija nauka i umetnosti.

Zgusta, L. (1998). The Terminology of name studies (In margine of Adrian Room's Guide to the Language of Name Studies). Names, 46(3), 189-203. 


\author{
SUMMARY \\ TERMINOLOGICAL PECULIARITIES AMONG ONOMASTIC META-NAMES \\ IN FRENCH, ENGLISH AND ITALIAN
}

This article presents the results of a review of terminological peculiarities among onomastic metanames ("names of proper names") that have been proposed by onomasticians or other language researchers, and have been accepted as naming terms within the scientific discourse or not. The analysis begins with an overview of the application of analytical model in the process of establishing the key phrases of onomastic terminology, formulated since the 1960s in the Slavic and international area. The historical analytical model consisted in the creation of descriptive terms according to the concept of a Czech onomastician Jan Svoboda, adapted to the Polish onomastics by Mieczysław Karaś. The descriptive formula of onomastic terms is reproduced in onomastic research currently conducted in Western Europe. At the same time, a tendency to create terms constructed in a synthetic way on the basis of combinations of elements from classical languages has developed (mainly a Greek or Latin prefixoid + the base onym). Proposals for such terms in the three linguistic areas of French, English and Italian were therefore reviewed, based on specific sources (among others H. Dorion \& J. Poirier, 1975, "Lexique des termes utiles à l'étude des noms de lieux"; A. Room, 1996, "An Alphabetical Guide to the Language of Name Studies"; and contributions by Enzo Caffarelli and other Italianspeaking authors from the years 1990-2021). The terminological units and their definitions are considered in terms of their onomasiological motivation confronted with the perspective of semasiology.

Keywords: onomastic terminology, peculiarities, proper names, meta-names, descriptive terms, synthetic terms 